\title{
Impact of COVID-19 on Stock Prices and Transaction Volume: Case Study of PT. Matahari Department Store, Tbk.
}

\author{
$1^{\text {st }}$ Setiati Utami Adiningsih, $2^{\text {nd }}$ Dewi Khairani ${ }^{2}, 3^{\text {rd }}$ Asep Saepudin Jahar $^{3}$, \\ $4^{\text {th }}$ Rodoni $^{4}, 5^{\text {th }}$ Arif Mufraini ${ }^{5}, 6^{\text {th }}$ Suherman Saleh $^{6}$ \\ \{ setiatiutami88@gmail.com ${ }^{1}$, dewi.khairani@uinjkt.ac.id ${ }^{2}$, asepjahar@uinjkt.ac.id ${ }^{3}$, \\ ahmad.rodoni@uinjkt.ac.id ${ }^{4}$, arif.mufraini@uinjkt.ac.id ${ }^{5}$, suherman.saleh18@mhs.uinjkt.ac.id $\left.{ }^{6}\right\}$ \\ Sy arif Hiday atullah State Islamic University of Jakarta, Indonesia ${ }^{123456}$
}

\begin{abstract}
The explanation of WHO in regards to COVID-19 is a worldwide pandemic that stresses all degrees of society Investors also started selling their risky assets. Every Indonesian economy was also affected. The stock market also showed its reaction. This study uses a comparative method, which is to compare stock prices and transaction volume before and after the announcement of the COVID-19 case in Indonesia using the paired sample t-test. The results showed that there were significant differences in stock prices and transaction volume before and after the announcement of the COVID-19 case in Indonesia.
\end{abstract}

Keywords: COVID-19, Stock Price, Transaction Volume

\section{Introduction}

At the end of 2019, the whole world was shocked by the emergence of the coronavirus or COVID-19 which was considered deadly. COVID-19 cases were first discovered in Wuhan, China. This virus then spread to almost all over the world, even in Indonesia. The first positive case was announced in Indonesia on March 2, 2020[1]. The development of this coronavirus caused everything to go into tumult. With the issuance of orders to stay at home, social distancing, physical distancing, work from home, closing shopping centers, hotels, public places, and flight restrictions. Practically the total of what parts have been influenced by the coronavirus. Such responses will influence business execution in nations with high sure cases [2].

As long as positive cases of the coronavirus continue to increase and migration persists, this virus will affect the economy and the stock market[2]. The world financial circumstance declined with the development of the coronavirus. Although the exact impact of the global economy is not yet known, the stock markets of the United States, Europe, and Asia experienced a sharp decline, the stock market experienced a decline of more than $20 \%$ [3]. In Indonesia, there has been much unemployment, the value of imports has decreased, even the domino effect of the cancellation of domestic and international flights has led to a decline in foreign tourists, decreased revenue from the air service sector, and decreased hotel occupancy [4]. 
The stock exchange has also been affected by the emergence of the coronavirus. Investors' concerns are increasing as new cases are added every day. Major events can significantly affect the stock market[5]. The COVID-19 outbreak has affected investment and the business environment in China[6]. Investors' concerns are increasing along with the addition of new cases every day, this makes trading volume and stock prices in the stock market drop dramatically[7], [8]. Market sentiment responded quickly to the outbreak and even more quickly with social media, which spurred trading activity and caused stock movements to price extremes [9]. The pandemic has created risks and uncertainties in global financial markets[3]. Stock exchanges in South Korea noted that trading volume has decreased by nearly $4 \%$. WHO announces that COVID-19 is a global pandemic, it makes investors sell risky assets, KOSPI trade falls more than 5\%[10]. In Indonesia, the IHSG reached its lowest point in history at Rp3,937[11]. Several sectors performed better during the COVID-19 outbreak, especially the information technology sector and pharmaceuticals manufacturing, but the beverage, air transportation, transportation, wholesale, hotel, tourism, and retail sectors have bad permorfances [6], [12], [13].

Matahari Department Store is a retail company based in Indonesia. With social distancing policy, Matahari had to close its outlets nationally, this was done to avoid mass layoffs. Despite having Matahari.com e-commerce, the operational closure of outlets resulted in a decline in the condition of the retail business. With the closure of outlets nationally, LPPF's stock conditions moved towards a weakening trend[14]. As of 14 August 2020, the LPPF reached its lowest price of IDR 1,095 on 3 April 2020, while the lowest transaction volume reached 741,400 shares on 19 March 2020[11].

The purpose of this research is to compare whether there is a significant difference between stock prices and transaction volume before and after the announcement of the first COVID-19 case in Indonesia. The research question for this paper is to investigate the difference in the stock price of PT. Matahari Department Store, Tbk. before and after the national announcement of the first case of COVID-19. Also to determine whether there a significant difference in the transaction volume of PT. Matahari Department Store, Tbk. before and after the national announcement of the first case of COVID-19.

\section{Literature Study}

Ifa Nurmasari (2020), researched "Dampak COVID-19 terhadap Perubahan Harga Saham dan Volume Transaksi (Studi Kasus pada PT. Ramayana Lestari Sentosa, Tbk.)". The results showed that there were significant differences in stock prices and transaction volume before and after the announcement of the COVID-19 case in Indonesia.

Siswantoro Siswantoro (2020), researched "The effect of the first COVID-19 case announcement on stock prices and stock trading totals". The results showed that there were significant differences in stock prices and transaction volume before and after the announcement of the COVID-19 case in Indonesia.

Dayong Zhang, Min Hua, and Qiang Ji (2020), research on "Financial Markets Under the Global Pandemic of COVID-19". The results show that the risk of global financial markets has increased in response to the COVID-19 pandemic. The great uncertainty due to the pandemic and the economic downturn makes the market very volatile and unpredictable.

Dao Le Trang Anh and Christopher Gan (2020), research on "The Impact of the COVID19 Lockdown on Stock Market Performance: Evidence from Vietnam". The results showed 
that the increase in daily positive cases and pre-lockdown in Vietnam had a significant negative effect on stock returns in Vietnam. In other words, it is not surprising that COVID-19 pandemic is affecting the stock market in Vietnam. Meanwhile, the lockdown has a significant positive effect on the performance of Vietnam's stocks because it increases investor confidence in the Vietnamese government's reaction so that the value of shares that are in low value again helps improve the performance of Vietnam's stock market.

Abdullah M. Al-Awadhi, Khaled Alsaifi, Ahmad Al-Awadhi, and Salah Alhammadi (2020), research on "Death and Contagious Infectious Diseases: Impact of the COVID-19 Virus on Stock Market Returns". The results showed that stock returns were significantly negatively related to daily growth in total confirmed cases and daily growth in total cases of death caused by COVID-19.

\subsection{Stock Price}

A company can sell its ownership rights in the form of shares (stock)[15]. Shares are of two types, namely common stock and preferred stock. Preferred stocks are stocks that have a mixture of bonds and normal stocks. If the company provides only one offering class, these offers are mostly common stock. Investors make equity participation through shares to expect a profit. The level of profit that will be obtained by investors is commonly known as stock returns. The stock price is the price obtained at the close of the stock market during the observation period. This investor's rate of return is strongly influenced by stock prices. If investors buy the stock price at a low price and sell at a high price, the investor will get capital gains. Conversely, if you buy at a high price and sell at a low price, investors will experience capital loss.

$\mathrm{H}_{1}$ : There is a significant difference in stock prices before and after the first announcement of COVID-19 in Indonesia at PT. Matahari Department Store, Tbk.

\subsection{Stock Price}

The transaction volume is the total shares traded in a certain period. Transaction volume reflects the power between supply and demand, which is a manifestation of investor behavior[16]. The volume of a stock transaction reflects the investor's interest in buying or selling shares of a company. The transaction volume value is not the same as the stock price, so if the transaction volume value is high, it is not certain that the price of a share will also be high. High transaction volume value can occur if there is a good event[17].

$\mathrm{H}_{1}$ : There is a significant difference in the volume of transactions before and after the first announcement of COVID-19 in Indonesia at PT. Matahari Department Store, Tbk.

\section{Research Methods}

Comparative research is research that compares one data to another[18]. This study is included in a comparative study because this study compares stock prices and transaction volume before the announcement of the first COVID-19 case in Indonesia and after. This study uses secondary data, namely stock prices and transaction volume from PT. Matahari Department Store, Tbk. taken from the yahoo finance website. The data used is data taken 30 days before and after the announcement of the first positive COVID-19 case in Indonesia, 
namely March 2, 2020. The stock price used is the price at the time of closing or the closing price. The data used are daily data while the transaction volume used is the daily share transaction volume of PT. Matahari Department Store, Tbk.

This study using a paired sample t-test. This test is used to measure how much difference the stock price and the share transaction volume of PT. Matahari Department Store, Tbk, before the announcement of the COVID-19 case which occurred for the first time in Indonesia and after the announcement. The data in this study were processed using SPSS version 16.0.

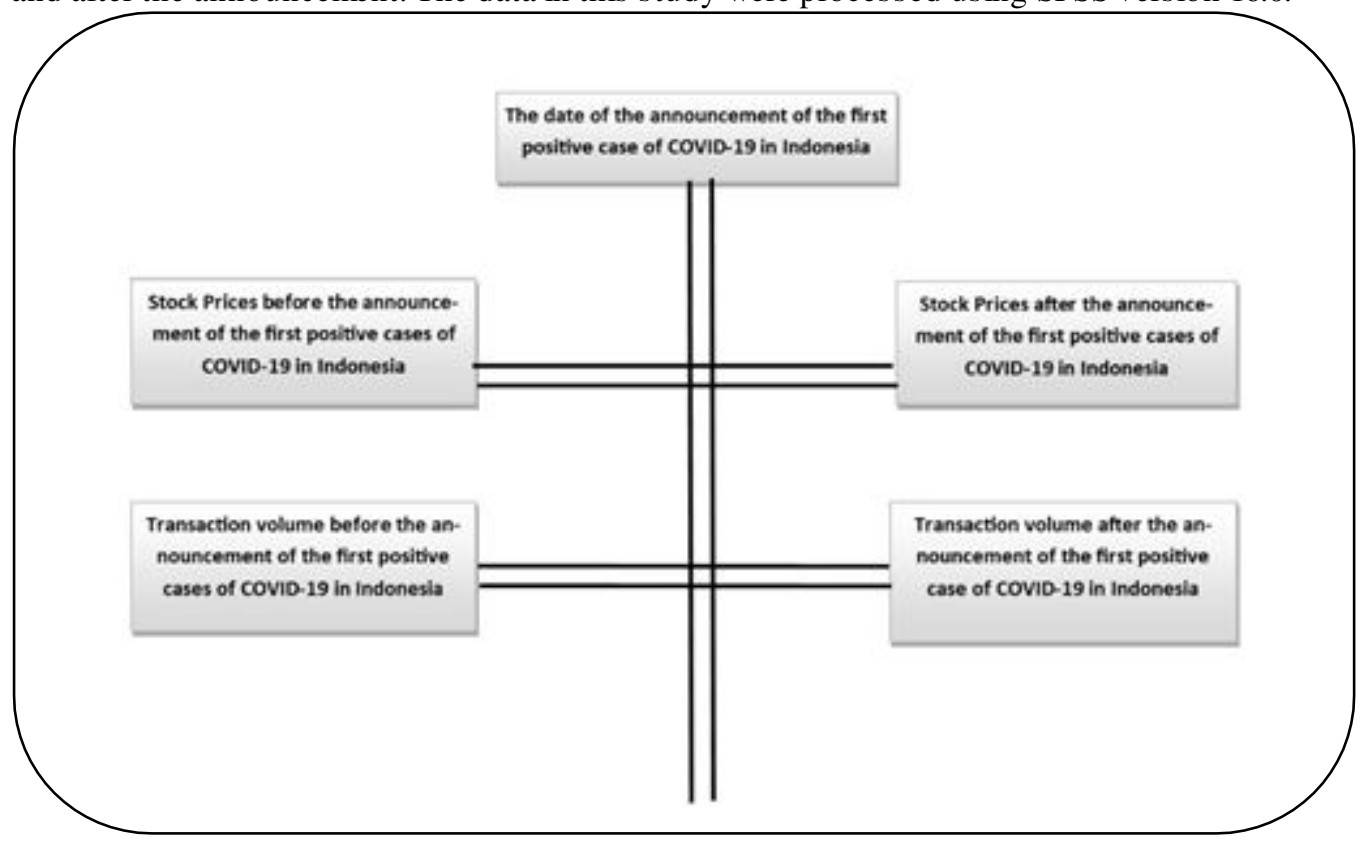

Fig. 1. Comparative research on stock prices and share transaction volume when the announcement of COVID-19 in Indonesia

\section{Result and Discussion}

4.1 The difference in the stock price of PT. Matahari Department Store, Tbk. before and after the announcement of the first case of COVID-19 in Indonesia.

Table 1. Descriptive Statistics of Stock Price

\begin{tabular}{lrrrrr}
\hline & N & \multicolumn{1}{c}{ Mean } & Standard Deviation & Minimum & Maximum \\
\hline X1 & 30 & $3,403.3$ & 310.83129 & 2940.00 & 4150.00 \\
X2 & 30 & $1,792.3$ & 668.60861 & 1095.00 & 3210.00 \\
\hline
\end{tabular}

Table 1 shows the descriptive statistical results of stock prices before the announcement of the COVID-19 case in Indonesia and after. The stock price before the announcement of the COVID-19 case in Indonesia had an average of IDR 3,403.3 and the stock price after the announcement of a positive case in Indonesia had an average of IDR 1,792.3. Before the 
announcement of the COVID-19 case in Indonesia, the maximum stock price reached IDR 4,150 on January 20, 2020, and a minimum value of IDR 2,940 on January 31, 2020. After the announcement of the COVID-19 case in Indonesia, the stock price only reached a maximum value of IDR 3,210 on March 4, 2020, and the minimum value was IDR 1,095 on April 3, 2020.

Table 2. One-Sample Kolmogorov-Smirnov Test Stock Price

\begin{tabular}{llrr}
\hline & & \multicolumn{1}{c}{ X1 } & \multicolumn{1}{c}{ X2 } \\
\hline $\mathrm{N}$ & & 30 & 30 \\
Normal Parameters a & Mean & $3.4033 \mathrm{E} 3$ & $1.792 \mathrm{E} 3$ \\
& Std. Deviation & $3.10831 \mathrm{E} 2$ & $6.68609 \mathrm{E} 2$ \\
Most Extreme Differeces & Absolute & .164 & .232 \\
& Positive & .164 & .232 \\
& Negative & -.098 & -.148 \\
Kolmogorov-Smirnoc Z & & .896 & 1.269 \\
Asymp. Sig. (2-tailed) & & .399 & .080 \\
\hline
\end{tabular}

a. Test distribution is Normal

Table 2 shows the One-Sample Kolmogorov-Smirnov Test of the stock price. The requirements that must be met before conducting the paired sample t-test are that the data must be normally distributed, therefore a data normality test is required. This stock price data normality test uses the Kolmogorov-Smirnov. The stock price interpretation value before the announcement of the first COVID-19 case in Indonesia was 0.896 and the stock price interpretation value after the announcement of the first COVID-19 case in Indonesia was 1,269 . Both have an interpretation value above 0.05 , it can be stated that the stock price data meet the normality assumption or the data is normally distributed.

Table 3. Paired Samples Test of Stock Prices

\begin{tabular}{|c|c|c|c|c|c|c|c|c|c|}
\hline & & \multicolumn{5}{|c|}{ Paired Differences } & \multirow[b]{3}{*}{$\mathrm{t}$} & \multirow[b]{3}{*}{ df } & \multirow{3}{*}{$\begin{array}{l}\text { Sig. (2- } \\
\text { tailed) }\end{array}$} \\
\hline & & \multirow[b]{2}{*}{ Mean } & \multirow{2}{*}{$\begin{array}{c}\text { Std. } \\
\text { Deviation }\end{array}$} & \multirow{2}{*}{\begin{tabular}{|c} 
Std. Mean \\
Error
\end{tabular}} & \multicolumn{2}{|c|}{$\begin{array}{c}5 \% \text { Confidence } \\
\text { Interval of } \\
\text { Difference } \\
\end{array}$} & & & \\
\hline & & & & & Lower & Upper & & & \\
\hline Pair 1 & $\mathrm{X} 1-\mathrm{X} 2$ & $\begin{array}{r}1.6110 \\
0 \mathrm{E} 3\end{array}$ & 483,65419 & 88.30277 & $\begin{array}{r}1430,400 \\
56\end{array}$ & $\begin{array}{r}1791,59 \\
944\end{array}$ & $\begin{array}{r}18,24 \\
4\end{array}$ & 29 & .000 \\
\hline
\end{tabular}

Table 3 shows the results of data processing from the paired sample t-test of stock prices which are operated using SPSS version 16.0. In the table, it can be seen that the significance value is smaller than 0.05 . This value indicates that $\mathrm{H}_{1}$ is accepted and $\mathrm{H}_{0}$ is rejected, which means that there is a significant difference between the stock price of PT. Matahari Department Store, Tbk. before and after the announcement of the first COVID-19 case in Indonesia. Table 3 also shows the difference in the average value of the stock price of PT. Matahari Department Store, Tbk. before and after the announcement of the first COVID-19 
case in Indonesia, amounting to Rp1,611. The value is positive, this indicates that the stock price before the announcement has an average value greater than the average value of the stock price after the announcement. This indicates a decline in the stock price of PT. Matahari Department Store, Tbk. caused by the COVID-19 pandemic. This is in line with previous research[3], [6], [17], [19]. but not by research[20]. The decline in stock prices that occurred was caused by investors' concerns over the COVID-19 pandemic. This is driven by the presence of coverage on social media which encourages the movement of stocks to extreme prices [9]. Meanwhile, in Anh's research, it was stated that the Stock Market in Vietnam had a significant positive effect. Even though it had experienced a decline due to a shocking event during the pre-lockdown, during the implementation of the lockdown with the reaction from the government in handling COVID-19 in Vietnam, it increased investor confidence so that stock prices increased again and improved the performance of the stock market in Vietnam[20].

4.2 The difference in the Transaction Volume of PT. Matahari Department Store, Tbk. before and after the announcement of the first case of COVID-19 in Indonesia.

Table 4. Descriptive Statistics of Transaction Volume

\begin{tabular}{rrrrrl}
\hline & $\mathrm{N}$ & \multicolumn{1}{c}{ Mean } & Standard Deviation & Minimum & Maximum \\
\hline X1 & 30 & $6,097,197$ & $4.08471 \mathrm{E} 6$ & $2,025,200$ & $20,079,400$ \\
X2 & 30 & $18,622,660$ & $1.49374 \mathrm{E} 7$ & 741,400 & $49,779,100$ \\
\hline
\end{tabular}

Table 4 shows the results of descriptive statistics on transaction volumes before the announcement of the COVID-19 case in Indonesia and after. The average transaction volume before the announcement of the COVID-19 case in Indonesia was 6,097,197 and the transaction volume after the announcement of positive cases in Indonesia had an average of $18,622,660$. The data used are 30 data taken from 30 days before the announcement of the first COVID-19 case in Indonesia and 30 data taken from 30 days after the announcement of the first COVID-19 case in Indonesia. Before the announcement of the Covid-19 case in Indonesia, the volume of share transactions of PT. Matahari Department Store, Tbk. reached a maximum value of 20,079,400 shares on January 20, 2020, and a minimum value of 2,025,200 shares on February 11, 2020. After the announcement of the COVID-19 case in Indonesia, the volume of shares transaction reached a maximum of 49,779,100 shares on April 3, 2020, and the minimum number was 741,400 shares on March 19, 2020.

Table 5. One-Sample Kolmogorov-Smirnov Test Transaction Volume

\begin{tabular}{llrr}
\hline & & X1 & X2 \\
\hline $\mathrm{N}$ & & 30 & 30 \\
Normal Parameters a & Mean & $6.0972 \mathrm{E} 6$ & $1.8623 \mathrm{E} 7$ \\
& Std. Deviation & $4.08471 \mathrm{E} 6$ & $1.49374 \mathrm{E} 7$ \\
\multirow{3}{*}{ Most Extreme Differeces } & Absolute & .224 & .161 \\
& Positive & .224 & .161 \\
& Negative & -159 & -116 \\
Kolmogorov-Smirnoc Z & & .896 & 1,225
\end{tabular}


a. Test distribution is Normal

Table 5 shows the One-Sample Kolmogorov-Smirnov Test transaction volume. The requirements that must be met before carrying out the Paired Sample t-Test are that the data must be normally distributed, therefore a data normality tes $t$ is required. This stock price data normality test uses the Kolmogorov-Smirnov. The interpretation value of the transaction volume before the announcement of the first COVID-19 case in Indonesia was 1,225 and the value of the stock price interpretation after the announcement of the first COVID-19 case in Indonesia was 0.883 . Both have an interpretation value above 0.05 , so it can be stated that the transaction volume data meet the normality assumption or the data is normally distributed.

Table 6. Paired Samples Test of Transaction Volume

\begin{tabular}{|c|c|c|c|c|c|c|c|c|c|}
\hline & & \multicolumn{5}{|c|}{ Paired Differences } & \multirow[b]{3}{*}{$\mathrm{t}$} & \multirow[b]{3}{*}{ df } & \multirow{3}{*}{$\begin{array}{l}\text { Sig. (2- } \\
\text { tailed) }\end{array}$} \\
\hline & & \multirow[b]{2}{*}{ Mean } & \multirow{2}{*}{$\begin{array}{c}\text { Std. } \\
\text { Deviation }\end{array}$} & \multirow{2}{*}{$\begin{array}{l}\text { Std. Mean } \\
\text { Error }\end{array}$} & \multicolumn{2}{|c|}{$\begin{array}{l}95 \% \text { Confidence } \\
\text { Interval of } \\
\text { Difference }\end{array}$} & & & \\
\hline & & & & & Lower & Upper & & & \\
\hline Pair 1 & $\mathrm{X} 1-\mathrm{X} 2$ & $\begin{array}{l}- \\
1.252 \\
55 \mathrm{E} 7\end{array}$ & $1.64365 \mathrm{E} 7$ & $\begin{array}{l}3,00088 \mathrm{E} \\
6\end{array}$ & $\begin{array}{l}- \\
1.86630 \\
\text { E7 }\end{array}$ & $\begin{array}{l}- \\
6.38797 \\
\text { E6 }\end{array}$ & - & 29 & .000 \\
\hline
\end{tabular}

Table 6 shows the results of data processing from the paired sample t-test transaction volume operated using SPSS version 16.0. In the table, it can be seen that the significance value is smaller than 0.05 . This value indicates that $\mathrm{H}_{1}$ is accepted and $\mathrm{H}_{0}$ is rejected, which means that there is a significant difference between the transaction volume of PT. Matahari Department Store, Tbk. before and after the announcement of the first COVID-19 case in Indonesia. Table 6 also shows the difference in the average value of the transaction volume of PT. Matahari Department Store, Tbk. before and after the announcement of the first COVID19 case in Indonesia, amounting to -12525463.3. The value is negative, this indicates that the transaction volume before the announcement has an average value smaller than the average value of the stock price after the announcement. This indicates an increase in the average transaction volume of PT. Matahari Department Store, Tbk. caused by the COVID-19 pandemic.

PT. Matahari Department Store, Tbk. experienced a significant increase in stock transaction volume due to the COVID-19 case in Indonesia, this is in line with the previous research [3], [6], [17], [19], but not with the research[20]. The increase in the volume of stock transactions occurred due to the increase in the buying and selling activities of shares at PT. Matahari Department Store, Tbk. The increase in the volume of transactions that occurred was not followed by an increase in share prices. This incident shows that many investors are selling their shares because of the concerns and pessimism of investors who will suffer losses due to economic uncertainty and decline due to the COVID-19 pandemic[3]. This panic has intensified with the fear that the stock market will experience a global downturn in the future[2]. While research[20], explained that the Vietnamese stock market has returned to life and is attracting capital inflows from investors in line with the increasing confidence of investors due to the reaction of the Vietnamese government in handling COVID-19. 


\section{Conclusion}

The conclusion of this study is to test paired sample t-Test, from the stock price of PT. Matahari Department Store, Tbk. before and after the announcement of the COVID-19 case in Indonesia, there is a significant difference. This is indicated by the sig value of $0.00<0.05$. Likewise for the volume of transactions from PT. Matahari Department Store, Tbk. before and after the announcement of the COVID-19 case in Indonesia, there is a significant difference. This is indicated by the sig value of $0.000<0.05$.

With the COVID-19 case, all Matahari Department Store outlets closed nationwide. Even though it has been selling online through its e-commerce, namely Matahari.com, the company still shows a decline in performance due to the closure of its operational outlets. Therefore, companies should maximize the use of Matahari.com to increase sales and turnover. That way, investors will be interested in buying company shares because of the increased income generated.

Acknowledgments. This paper was supported by PPM UIN Syarif Hidayatullah Jakarta for KKN-DR year 2020. 


\section{References}

[1] A. Prasetia, "2 Orang Indonesia Positif Kena Corona di Wilayah RI," 2020. https:/health.detik.com/berita-detikhealth/d-4921506/2-orang-indonesia-positif-kena-corona-diwilay ah-ri (accessed Aug. 15, 2020).

[2] D. I. Okorie and B. Lin, "Stock markets and the COVID-19 fractal contagion effects," Financ. Res. Lett., 2020, doi: 10.1016/j.frl.2020.101640.

[3] D. Zhang, M. Hu, and Q. Ji, "Financial markets under the global pandemic of COVID-19," Financ. Res. Lett., 2020, doi: 10.1016/j.frl.2020.101528.

[4] "Seberapa Besar Pengaruh Covid-19 Terhadap Perekonomian Indonesia," 2020. https://www.kelaspintar.id/blog/inspirasi/pengaruh-covid-19-terhadap-perekonomian-indonesia4842/ (accessed Aug. 15, 2020).

[5] T. Zach, "Political Events and the Stock Market: Evidence from Israel," SSRN Electron. J., 2005, doi: 10.2139/ssrn.420242.

[6] A. M. Al-Awadhi, K. Alsaifi, A. Al-Awadhi, and S. Alhammadi, "Death and contagious infectious diseases: Impact of the COVID-19 virus on stock market returns," J. Behav. Exp. Financ., 2020, doi: 10.1016/j.jbef.2020.100326.

[7] W. Sun, "H7N9 not only endanger human health but also hit stock marketing," $A d v$. Dis. Control Prev., 2017, doi: 10.25196/adcp 201711.

[8] H. Liu, A. Manzoor, C. Wang, L. Zhang, and Z. Manzoor, "The COVID-19 outbreak and affected countries stock markets response," Int. J. Environ. Res. Public Health, 2020, doi: 10.3390/ijerph17082800.

[9] D. C. Broadstock and D. Zhang, "Social-media and intraday stock returns: The pricing power of sentiment," Financ. Res. Lett., 2019, doi: 10.1016/j.frl.2019.03.030.

[10] Faisal Yunianto, "Saham Korea Selatan jatuh dipicu ketakutan terhadap COVID-19 ANTARA News,” 2020. https://www.antaranews.com/berita/1351722/saham-korea-selatan-jatuhdipicu-ketakutan-terhadap-covid-19 (accessed Aug. 15, 2020).

[11] "Yahoo Finance - Stock Market Live, Quotes, Business \& Finance News." https://finance.y ahoo.com/ (accessed Aug. 15, 2020).

[12] M. H. Chen, S. C. (Shawn) Jang, and W. G. Kim, "The impact of the SARS outbreak on Taiwanese hotel stock performance: An event-study approach," Int. J. Hosp. Manag., 2007, doi: 10.1016/j.ijhm.2005.11.004.

[13] Chun-Da Chen, Chin-Chun Chen, Wan-Wei Tang, and Bor-Yi Huang, "The Positive and Negative Impacts of the Sars Outbreak: A Case of the Taiwan Industries," J. Dev. Areas, 2009, doi: 10.1353/jda.0.0041.

[14] L. Ningsih, "Matahari vs Ramayana saat Corona Menghantam, Mana yang Paling Banyak Memakan Korban? Gak Nyangka...," 2020. https://www.wartaekonomi.co.id/read280384/mataharivs-ramay ana-saat-corona-menghantam-mana-y ang-p aling-bany ak-memakan-korban-gak-ny angka (accessed Aug. 15, 2020).

[15] J. Hartono, Teori portofolio dan analisis investasi (edisi Kesebelas). 2017.

[16] I. Indarti and D. Purba, "Analisis Perbandingan Harga Saham dan Volume Perdagangan Saham Sebelum dan Sesudah Stock Split," J. Ilmu Ekon. ASET, 2011.

[17] I. Nurmasari, "Dampak Covid - 19 Terhadap Perubahan Harga Saham dan Volume Transaksi (Studi Kasus Pada PT. Ramay ana Lestari Sentosa, Tbk.)," J. Sekuritas, 2020.

[18] P. D. Sugiy ono, metode penelitian kuantitatif, kualitatif,dan R\&D. 2016.

[19] S. Siswantoro, "Efek diumumkanny a kasus pertama Covid-19 terhadap harga saham dan total saham y ang diperdagangkan," J. Akuntansi, Keuangan, dan Manaj., vol. Vol 1, No, pp. 227-238, 2020, doi: https://doi.org/10.35912/jakman.v1i3.38.

[20] D. L. T. Anh and C. Gan, "The impact of the COVID-19 lockdown on stock market performance: evidence from Vietnam,” J. Econ. Stud., 2020, doi: 10.1108/JES-06-2020-0312. 